\title{
SANKSI PIDANA PELAKU LGBT DALAM PERSPEKTIF FIQH JINAYAH
}

\section{QOMARAUZZAMAN}

Dosen Fakultas Syariah Program Studi Ahwal Syakhsiyah

Sekolah Tinggi Agama Islam Swasta (STAIS) Mempawah

Qomaruzzaman84@gmail.com

\begin{abstract}
Islam probibits Lesbian, Gay, Bisexual, and Transgender because of ignoring the human nature. Thus, on Jinayah perspective (Islamic Criminal Law) the LGBT behaviors are categorised as Jarimah (Criminality), and the subjects of LGBT should be punished legally ("uqubah). Furthermore, the classification of lav on LGBT to create the justice related to Islam as a religion (bifdz al-di). genetic issue (bifdz an-Nasl), intelligence (bifdz, al-'aql), soul (hifdz, an-Nafs) and poverty (bifdz, al-mal). Furthermore, based on Jinayah perspective, homosexual (al-Liwath / as-Sihaq) is classified as jarimah zina so the subjects would be whipped a bundred times and isolated for one year (if the doer is ghairu mubshan). Then, if the subject is mubshan, he/ she nould be thrown by stones until death. Meanwbile, the bisexual people would be sanctioned by ta'zir; the government (uli al-'amr) would decide the punishment.
\end{abstract}

Keywords: LGBT, Jinayah, Hudud, Ta'zir.

\section{PENDAHULUAN}

Fenomena Lesbian, Gay, Biseksual dan Transgender (LGBT) menjadi perdebatan yang panas di kalangan masyarakat Indonesia, terlebih setelah pada tahun 2015 lalu muncul wacana serta desakan agar pemerintah membuat regulasi untuk melegalkan aktivitas komunitas tersebut. Wacana pelegalan LGBT di Indonesia tidak lepas dari efek putusan Mahkamah Agung Amerika Serikat (AS) yang melegalkan pernikahan sesama jenis. ${ }^{1}$

Jauh sebelum Amerika Serikat melegalkan LGBT, beberapa negara Eropa dan Amerika telah lebih dahulu melegalkan pasangan LGBT tersebut, ${ }^{2}$ dan efek pelegalan ini berdampak juga di Indonesia yang notabene mayoritas beragama Islam. Dari hasil survei CIA yang dilansir oleh "sixpackmagazinedotnet.", populasi LGBT di Indonesia menduduki ranking ke-5 terbesar di dunia, setelah China, India, Eropa, dan Amerika. Sedangkan menurut data laporan Kementerian Kesehatan yang dikutip dari Komisi Penanggulangan AIDS Nasional mengungkap jumlah Lelaki berhubungan

1 Amerika Serikat (AS) pada tanggal 26 Juni 2015 melalui putusan Mahkamah Agung yang dipimpin Hakim Anthony Kennedy resmi melegalkan pernikahan sejenis. Sebagaimana dikutip harian New York Times, Hakim Agung Kennedy mengatakan "They ask for equal dignity in the eyes of the law, the Constitution grants them that rights". Saumi Rizqiyanto. "Alasan Amerika Melegalkan Pernikahan Sesama Jenis”, http://www.kompasiana.com/saumiere/alasanamerika-melegalkan-pernikahan-sesama-jenis, Akses 16 September 2016.

2 Dari data yang penulis kumpulkan melalui berbagai sumber terdapat 22 negara yang melegalkan LGBT, negara tersebut adalah: 1. Belanda (2001), 2. Belgia (2003), 3. Spanyol (2005), 4. Kanada (2005), 5. Afsel (2006), 6. Norwegia (2009), 7. Swedia (2009), 8. Portugal (2010), 9. Islandia (2010), 10. Argentina (2010), 11. Denmark (2012), 12. Brazil (2013), 13. Inggris (2013), 14. Prancis (2013), 15. Selandia Baru (2013), 16. Uruguay (2013), 17. Skotlandia (2014), 18. Luxemburg (2015), 19. Finlandia (2015), 20. Slovenia (2015), 21. Irlandia (2015), dan 22. Meksiko (2015). 
Seks dengan Lelaki (LSL) alias gay sudah mencapai angka jutaan. Estimasi Kemenkes pada 2012, terdapat 1.095.970 LSL baik yang tampak maupun tidak dan semu tersebar di berbagai daerah.

Merujuk data pelaku LGBT di atas, masyarakat Indonesia yang merupakan mayoritas muslim terbesar di dunia adalah wajar menolak pelegalan tersebut, bahkan jangankan untuk dilegalkan, keberadaannya pun sangat ditentang karena aktivitas LGBT ini sangat bertentangan dengan agama. Islam dengan tegas menolak penyimpangan seksual seperti itu. Homoseksual dan sejenisnya adalah perbuatan keji yang dilarang keras dalam Islam sebagaimana ditegaskan dalam atQur’an:

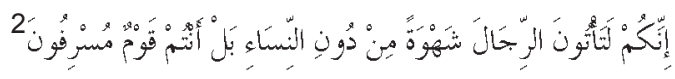

Sesunggubnya kamu mendatangi lelaki untuk melepaskan nafsumu (kepada mereka), bukan kepada wanita, malah kamu ini adalah kaum yang melampani batas.

Islam sangat melarang dan melaknat perbuatan homoseksual (LGBT), karena hal ini dipandang tidak sesuai dengan kodrat penciptaan manusia yang diciptakan untuk hidup berpasangepasangan melalui pernikahan, ${ }^{3}$ dan pernikahan merupakan ikatan fundamental yang berakar pada nilai-nilai suci. Karena itu, dengan melegalkan eksistensi LGBT apalagi perkawinan sesama jenis sama dengan merendahkan institusi pernikahan. Islam menjelaskan bahwa hikmah penciptaaan jenis kelamin laki laki dan perempuan adalah untuk kelestarian jenis manusia dengan segala martabat kemanusiaannya. Perilaku seks yang menyimpang seperti LGBT tentu sangat bertentangan dengan tujuan itu. Islam dengan tegas melarang semua perilaku seks yang menyimpang dari syariah. Oleh karenanya, pelaku LGBT harus dihukum seberat mungkin, dan hukuman/sanksi tersebut diatur dalam hukum Pidana Islam (Fiqh Jinayah), lalu bagaimana hukuman ('uqubah) yang diatur di dalam Islam terhadap pelaku LGBT tersebut? Tulisan ini akan mengurai bagaimana sanksi terhadap pelaku LGBT yang sesuai dengan fiqh Jinayah.

\section{DISKURSUS TENTANG LBGT}

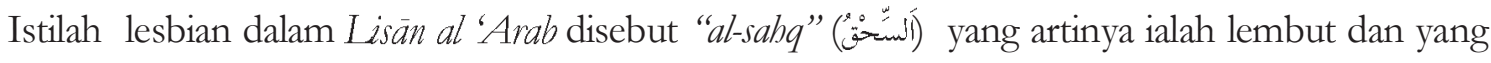
halus. Kemudian dari kata ini, berkembang kalimat dilakukan oleh dua orang wanita. ${ }^{4}$ Adapun secara umum istilah Lesbian ${ }^{5}$ merupakan istilah

${ }^{1}$ Daerah terbesar pelaku LGBT adalah Jawa Barat dengan jumlah 300.198 dan 4.895 diantaranya merupakan penderita HIV/AIDS. Jawa Tengah memiliki pelaku LGBT dengan jumlah 218.227 dan 11.951 orang terindikasi penderita HIV/AIDS. Sedangkan untuk DKI Jakarta Sebanyak 27.706 pelaku LGBT dan sebanyak 5.550 orang diduga menderita HIV/AIDS. "Berapa Sebenarnya Jumlah Gay di Seluruh Indonesia?" http://nasional.republika.co.id. Akses 10 September 2016.

2 Al-A'raf, (7) : 80.

${ }^{3}$ Sebagaimana ditegaskan dalam surat An Nisaa (4) : 1 :

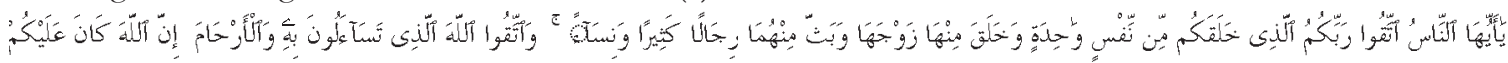

زرقِينَا

"Wahai manusia, bertaqwalah kamu sekalian kepada Tuhanmu yang telab menjadikan kamu satu diri, lalu Ia jadikan daripadanya jodohnya, kemudian Dia kembangbiakkan menjadi laki-laki dan perempuan yang banyak. sek.ali."

${ }^{4}$ Alusy, Rubul Ma'an", Volume VIII, (ttp. Tnp: tt). hlm. 172-173. Lihat juga Ahmad Warson Munawwir, Kamus Al-Munawir, cet. XIV, (Surabaya; Pustaka Progressif, 1997), hlm. 616.

5 Lesbian/ lesbianisme merupakan istilah yang diambil dari sebuah nama pulau Lesbos, yang mana perempuannya di daerah tersebut menyukai sesama jenis. Sehingga seorang wanita yang mengalami kecendrungan 
perempuan yang mengarahkan orientasi seksualnya kepada sesama perempuan. Istilah ini juga merujuk kepada perempuan yang mencintai perempuan baik secara fisik, seksual, emosional, atau secara spiritual. ${ }^{1}$

Gay dalam bahasa arab di sebut dengan istilah "al-Liwäth" (big') yang berarti orang yang melakukan perbuatan seperti perbuatan kaum Nabi Luth, pelakunya disebut "al-Lüthìyu" ("وطي"), yang berarti laki-laki yang melakukan hubungan seksual dengan laki-laki. ${ }^{2}$ Kaum gay dalam melakukan senggama biasanya dengan memanipulasi alat kelamin pasangannya dengan memasukkan penis ke dalam mulut (oral erotisme), dengan menggunakan bibir (fellatio), dan lidah (cunnilingus) untuk menggelitik. Metode lainnya adalah dengan memanipulasi penis di selasela paha (intervemora coitus). ${ }^{3}$

Adapun Biseksualitas adalah salah satu dari tiga klasifikasi utama orientasi seksual, bersama dengan heteroseksualitas dan homoseksualitas, yang masing-masing merupakan bagian dari rangkaian kesatuan heteroseksual-homoseksual. ${ }^{4}$ Biseksualitas merupakan ketertarikan romantis, ketertarikan seksual, atau kebiasaan seksual kepada pria maupun wanita. Istilah ini umumnya digunakan dalam konteks ketertarikan manusia untuk menunjukkan perasaan romantis atau seksual kepada pria maupun wanita sekaligus. Istilah ini juga didefinisikan sebagai ketertarikan romantis atau seksual pada semua jenis identitas gender atau pada seseorang tanpa mempedulikan jenis kelamin atau gender biologis orang tersebut, yang terkadang disebut panseksualitas.

Biseksual dapat dibagi menjadi tiga bagian yaitu, pertama seseorang yang melakukan hubungan seks lebih dari satu orang dalam melakukan hubungan intim pada satu kejadian, kedua seseorang yang melakukan hubungan seks dengan binatang, dan ketiga seseorang yang melakukan oral dengan benda yang ia sangat sukai. Para perilaku biseksual juga dapat melakukan hubungan seksual dengan sesama jenisnya ataupun lawan jenisnya.

Sedangkan Transgender adalah ketidaksamaan identitas gender seseorang terhadap jenis kelamin yang ditunjuk kepada dirinya. Transgender bukan merupakan orientasi seksual. Seseorang yang transgender dapat mengidentifikasi dirinya sebagai seorang heteroseksual, homoseksual, biseksual, maupun aseksual. ${ }^{5}$ Transgender merupakan suatu gejala ketidakpuasan seseorang karena merasa tidak adanya kecocokan antara bentuk fisik dan kelamin dengan kejiwaan ataupun adanya ketidakpuasan dengan alat kelamin yang dimilikinya. Ekspresinya bisa dalam bentuk dandanan, make up, gaya dan tingkah laku, bahkan sampai kepada operasi penggantian kelamin (Sex Reassignment Surgery).

Transgender dalam kitab-kitab fiqh disebut dengan khuntsa, yaitu orang yang memiliki dua jenis kelamin, kelamin laki-laki dan perempuan. Jika kelamin laki-laki lebih menonjol maka ia dihukumi

untuk tertarik dengan sesama wanita diidentikkan dengan kaum lesbos/lesbi. Lihat Marzuki Umar Sa'abah, Seks dan Kita, cet. ke-1, (Jakarta: Gema Insani Press, 1998), hlm. 146.

${ }^{1}$ Lihat https://id.wikipedia.org/wiki/Lesbian

2 Majma' at-Lughah al-'Arābiyah, al-Mu'jam al-IW'asith, cet. II, Jilid II, (Mishr: Dar al- Ma'ārif, 1393 II- 1973 M), hlm. 846.

${ }^{3}$ Marzuki., Seks., hlm. 146.

${ }^{4}$ https://id.wikipedia.org/wiki/Biseksualitas. Akses 10 September 2016.

${ }^{5}$ Ibid. 
sebagai laki-laki dan jika kelamin perempuan lebih tampak, maka ia dihukumi sebagai perempuan. Istilah khuntsa dibagi menjadi dua, yaitu khuntsa mukhannats dan khuntsa mutarajjil. Khuntsa Mubkannats yaitu laki-laki yang meniru/menyerupai (tasyabbuh) wanita dalam penampilan, tingkah laku dan cara bicara. Sebaliknya khuntsa, mutarajjil berarti perempuan yang meniru laki-laki dalam penampilan, tingkah laku dan cara bicara.

\section{SEJARAH HOMOSEKSUAL}

Homoseks merupakan perbuatan keji dan termasuk dosa besar, yang merusak etika, fitrah, agama, dan jiwa manusia. Homoseks menyimpang dari fitrah manusia karena fitrah manusia cenderung kepada hubungan biologis secara beterosex, yakni hubungan seks antara pria dan wanita. Perbuatan homoseks bukan hanya terdapat di zaman modern ini, tetapi telah terjadi pada zaman Nabi Luth, seperti yang dinyatakan dalam al-Qur'e an surat al-A'rāf, ayat: $80,81,82,83$, dan $84 .^{2}$

Dalam sejarahnya, Nabi Luth diutus oleh Allah untuk memperbaiki akidah serta akhlak kaumnya yang berdiam di negeri Sadum, Amurah, Adma, Sabubim, dan Bah', di tepi Laut Mati. Nabi Luth memilih tinggal di negeri yang paling besar dari kelima negeri itu, yaitu Sadum. Negeri Sadum mengalami kehancuran moral, kaum laki-laki lebih bersyahwat kepada sesama jenisnya yang berusia muda, dan tidak bersyahwat kepada kaum wanita. Ketika menyaksikan perbuatan kaumnya yang tidak bermoral itu, Nabi Luth menegur dan memperingatkan mereka untuk meninggalkan kebiasaannya. Ia mengajak untuk menyalurkan naluri seks sesuai dengan fitrah, yaitu melalui perkawinan antara pria dan wanita. Ajakan Nabi Luth ini mereka jawab dengan mengusirnya. Sementara itu, mereka terus mengerjakan perbuatan keji dan tidak bermaksud hendak meninggalkan kebiasaan mereka. Usaha Nabi Luth untuk menyadarkan kaumnya dari perbuatan keji tidak membawa hasil yang maksimal, karena sikap kaumnya yang ingkar terhadap ajaran agama. ${ }^{3}$ Perbuatan kaum Nabi Luth yang telah melampaui batas itu kemudian dibalas dengan cara memutarbalikkan negeri mereka, sehingga penduduk Sadum, termasuk istri Nabi Luth sendiri, terbenam bersamaan dengan terbaliknya negeri itu. $^{4}$

${ }^{1}$ Husain Al-Awaysyah, Al-Mausu'ah Al-Fiqhiyah Al-Muyassarah, juz 36, (ttp.: Kementrian Wakaf dan Urusan Agama Kuwait, 1983), hlm. 265.

2 80). Dan (Kami juga telah mengutus) Luth (kepada kaumnya). (Ingatlah) tatkala dia berkata kepada mereka: "Mengapa kamu mengerjakan perbuatan faabisyah itu, yang belum pernah dikerjakan oleh seorangpun (di dunia ini) sebelummu?", 81), Sesunggubnya kamu mendatangi lelaki untuke melepaskan nafsumu (kepada mereka), bukan kepada wanita, malah kamu ini adalah kaum yang melampaui batas. 82). Jawab kaumnya tidak lain banya mengatakan: "Usirlab mereka (Luth dan pengikut-pengikutnya) dari kotamu ini; sesunggubnya mereka adalah orang-orang yang berpura-pura mensucikan diri." 83). Kemudian Kami selamatkan dia dan pengikut-pengikutny a kecuali isterinya; dia termasuk orang-orang yang tertinggal (dibinasakan). 84). Dan Kami turunkan kepada mereka bujan (batu); maka perbatikanlah bagaimana kesudaban orang-orang yang berdosa itu.

${ }^{3}$ Rasyid Ridha, Tafsir al-Manar, (Kairo: Mathba'ah Hajari, 1950), hlm. 509-522. Lihat juga Ramlan Yusuf Rangkuti, "Homoseksual Dalam Perspektif Hukum Islam" dalam Jurnal Asy-Syir'abl Ilmu Syari'ah dan Hukum Vol. 46 No. I, (Januari-Juni 2012), hlm. 194-196.

${ }^{4}$ Sebagaimana dijelaskan dalam al-Qur'an Surat Hud, ayat 77, 78, 79, 80, 81, dan 82: 77). Dan tatkala datang utusan-utusan Kami (para malaikat) itu kepada Luth, dia merasa susah dan merasa sempit dadanya karena kedatangan mereka, dan dia berkata: "Ini adalah hari yang amat sulit. 78). Dan datanglah kepadanya kaumnya dengan bergegas-gegas. Dan sejak dabulu mereka selalu melakukan perbuatan-perbuatan yang keji[730]. Luth berkata: "Hai kaumku, inilah puteri-puteriku, mereka lebih suci bagimu, maka bertakwalah kepada Allah dan janganlah kamu mencemarkan (nama)ku terbadap tamuku ini. Tidak adakah di antaramu seorang yang berakal?" 79). Mereka menjawab: "Sesunggubnya kamu telab tabu babwa kami tidak mempunyai keinginanterbadap puteri-puterimu; dan sesunggubnya kamu tentu mengetabui apa yang sebenarnya kami kehendaki." 80). Luth 
Kendati kaum Luth telah dihancurkan oleh Allah ratusan abad yang lalu, namun homoseks tetap ada di tengah kehidupan manusia. Siksaan keras yang ditimpakan kepada kaum Luth tidaklah diambil sebagai pelajaran. Bahkan dunia dewasa ini dilanda revolusi seks yang jauh melampaui batas dan ketentuan agama. George Harvard dalam bukunya Revolusi Seks mengungkapkan:

"Kita tidak begitu khawatir terhadap bahaya nuklir yang mengancam kehidupan manusia di abad modern ini. Yang kita khawatirkan adalah serangan bom seks yang setiap saatdapat meledak, menghancurkan moral manusia."

Pandangan semacam ini juga dilontarkan oleh sejarawan Arnold Toynbee yang menyatakan, "Dominasi seks dewasa ini akan mengakibatkan runtuhnya peradaban manusia."1

Pernyataan para ahli ini didasarkan atas fakta empiris bahwa huhungan seks dewasa ini tidak lagi terbatas pada suami-istri atau dua insan berlainan jenis, tetapi telah jauh melebar kebentuk hubungan seks sesama jenis, baik homoseks maupun lesbian. Inilah yang melatarbelakangi tulisan James Ruston di harian New York Times yang menyatakan bahwa bahaya tenaga seks lebih besar daripada bahaya tenaga nuklir. Ini dapat dibuktikan dari catatan resmi Dewan Kesehatan Dunia, bahwa terdapat puluhan juta orang melakukan homoseks, tiga juta orang di antaranya di Amerika. ${ }^{2}$

Homoseksual sendiri di Indonesia bukanlah hal baru, bahkan rujukannya dapat dibaca dalam karya zaman Majapahit. Negarakertagama, yang mengisahkan baginda Hayam Wuruk (memerintah 1350-1365), yang gemar menari dalam pakaian perempuan dihadapkan para menterinya. ${ }^{3}$ Budaya homoseksual dapat juga ditemukan pada masyarakat Jawa Timur yang berkecimpung dalam dunia warok. Dalam dunia warok, demi menjaga ilmu kesaktian berupa kekebalan terhadap senjata tajam, setiap warok memiliki lelaki muda yang bertugas membantu pekerjaan rumah keluarga warok maupun kebutuhan seksual sang warok. ${ }^{4}$ Di Kalimantan, Suku Dayak Ngaju mengenal pendeta perantara yang mengenakan pakaian lawan jenis. Di Sulawesi Selatan pun ada fenomena serupa. Di kalangan suku Bugis, laki-laki yang diberi tugas menjaga pusaka, jabatannya diberi nama bissu. Dan seorang bissu diharapkan mengenakan pakaian perempuan dan manjauhi kontak dengan perempuan. ${ }^{5}$

Pada tahun 1969 di Jakarta mulai muncul organisasi Wadam yang bernama Himpunan Wadam Djakarta (HIWAD). Organisasi tersebut merupakan organisasi Waria pertama di Indonesia yang terletak di Jakarta. Organisai tersebut berdiri dan difasilitasi oleh Gubernur DKI Jakarta, Ali Sadkin. Dan sejak tahun 1982 hingga sekarang muncullah Organisasi gay terbuka, yang merupakan organisasi

berkata: "Seandainya aku ada mempunyai kekuatan (untuke menolakmu) atau kalau aku dapat berlindung kepada keluarga yang kuat (tentu aku lakukan)." 81). Para utusan (malaikat) berkata: "Hai Luth, sesunggubnya kami adalah utusan-utusan Tubanmu, sekali-kali mereka tidak akan dapat mengganggu kamu, sebab itu pergilah dengan membawa keluarga dan pengikut-pengikut kamu di akbir malam dan janganlah ada seorangpun di antara kamu yang tertinggal, kecuali isterimu. Sesunggubnya dia akan ditimpa azab yang menimpa mereka karena sesunggubnya saat jatubnya azab kepada mereka ialah di waktu subub; bukankah subuh itu sudah dekat?." 82). Maka tatkala datang azab Kami, Kami jadikan negeri kaum Luth itu yang di atas ke bawah (Kami balikekan), dan Kami hujani mereka dengan batu dari tanah yang terbakar dengan bertubi-tubi.

${ }^{1}$ Fathi Yakan, al-Isläm wa al-Jins, Terj. Syafril Halim, Islam dan Seks (Jakarta: Al-Hidayah, 1989), hlm. 78. Lihat juga Ramlan Yusuf., "Homoseksual., hlm. 198.

2 Murtadha Mutahhari, Manusia dan Agama, (Bandung: Mizan, 1984), hlm. 58 dalam Ibid.

3 Zunly Nadia, Waria, Laknat atau Kodrat, (Yogyakarta: Marwa, 2005), hlm.54.

${ }^{4}$ Ibid., hlm. 53.

${ }^{5}$ Ibid., hlm. 55. 
gay terbuka yang pertama di Indonesia, setelah itu diikuti dengan organisasi lainnya seperti: Persaudaraan Gay Yogyakarta (PGY), Indonesian Gay Society (IGS), dan Gaya Nusantara (GN) Surabaya. Setelah banyaknya kemunculan-kemunculan tersebut, organisasi gay mulai menjamur diberbagai kota besar seperti di Jakarta, Pekanbaru, Bandung dan Denpasar, Malang dan Ujung Padang. ${ }^{1}$

Pasca reformasi 1998, gerakan LGBT kian berkembang pesat dengan cakupan yang luas. Pada Desember 1998, Kongres Perempuan Indonesia secara resmi mengikutsertakan perwakilan dari lesbian, dan gay atau LBT. Pada tahun 2007 berdiri jaringan gay, waria dan lakilaki yang berhubungan seks dengan laki-laki lain yang disingkat GWL-INA dan mendapat dukungan secara nasional, maupun internasional. Pada tahun 2008, setelah konferensi internasional lesbian, gay, bisexual, trans and intersex association (ILGA) tingkat Asia yang ketiga di Chiang Mai, Thailand, enam organisasi LGBT yang berkantor pusat di Jakarta, Surabaya, dan Yogyakarta bergabung memperkuat gerakan mereka. Langkah ini menjadi awal forum LGBTIQ (Lesbian, Gay, Bisexual, Transgender, Intersex, and Queer) di Indonesia. Forum ini pada tahun 2012, sudah masuk dalam laporan masyarakat madani yang dikoordinir oleh Human Rights Working Group (HRWG) sebagai laporan berkala Dewan Hak Asasi Manusia PBB. ${ }^{2}$

\section{DAMPAK PERILAKU LBGT}

Dampak negatif yang ditimbulkan perbuatan LGBT sebagaimana perkataan jumhur ulama dan ijma' dari para shahabat mengatakan, "Tidak ada satu perbuatan maksiat pun yang kerusakannya lebih besar dibanding perbuatan homoseksual. Bahkan dosanya berada persis di bawah tingkatan kekufuran bahkan lebih besar dari kerusakan yang ditimbulkan tindakan pembunuhan. "Allah tidak pernah menguji dengan ujian yang seberat ini kepada siapa pun umat di muka bumi ini selain umat Nabi Luth. Ia memberikan siksaan kepada mereka dengan siksaan yang belum pernah dirasakan oleh umat mana pun. Hal ini terlihat dari beraneka ragamnya adzab yang menimpa mereka, mulai dari kebinasaan, dibolak-balikkannya tempat tinggal mereka, dijerembabkannya mereka ke dalam perut bumi dan dihujani bebatuan dari langit. Ini tak lain karena demikian besarnya dosa perbuatan tersebut.

Menurut Sayyid Sabiq, Islam melarang keras homoseks, karena mempunyai dampak yang negatif terhadap kehidupan pribadi dan masyarakat, antara lain:

a. Seorang homo tidak mempunyai keinginan terhadap wanita. Jika mereka melangsungkan perkawinan, sang istri tidak akan mendapatkan kepuasan biologis, karena nafsu berahi suami telah tertumpah ketika melangsungkan homoseks terhadap lakilaki yang diinginkannya. Akibatnya, hubungan suami-istri menjadi renggang, tidak tumbuh rasa cinta dan kasih sayang, dan tidak memperoleh keturunan, sekalipun istrinya subur dan dapat melahirkan.

b. Perasaan cinta dengan sesama jenis membawa kelainan jiwa yang menimbulkan suatu sikap dan perilaku ganjil. Seorang homo kadang-kadang berperilaku sebagai laki-laki dan kadang-kadang sebagai perempuan.

c. Mengakibatkan rusaknya saraf otak, melemahkan akal, dan menghilangkan semangat kerja.

\footnotetext{
1 “Sejarah Asal Usul Gay dan Waria Sampai Sekarang” http://danish56.blogspot.co.id, akses 16 September 2016.

2 "Perjalanan Organisasi LGBT di Indonesia", https://www.chanelmuslim.com.akses 15 September 2016.

3 Sayyid Sabiq, Figh al-Sunnah, juz VI, (Beirut: Dār al-Fikr, 1980), hlm. 361-365 lihat juga Ramlan Yusuf., “Homoseksual., hlm. 198-199.
} 
Di samping akibat negatif di atas, ada pula akibat yang sangat membahayakan bagi kelangsungan hidup seseorang, yakni berjangkitnya penyakit HIV/AIDS. Selain penyakit AIDS ada pula penyakit kelamin lainnya, yaitu sipilis. Menurut seorang ahli medis Prancis, di Prancis setiap tahunnya ada 30.000 orang meninggal karena penyakit ini. Sementara itu, di Amerika terdapat sekitar 30.000 sampai 40.000. Menurut para ahli, penyakit ini menular dengan hubungan seksual, seperti zina, homoseks, dan lesbian. Kuman sipilis berkembang biak melalui luka, yang menular dengan cepat. Penyakit ini sangat berbahaya, penderitanya dapat menjadi lumpuh karena lemahnya daya tahan tubuh, dan membawa kematian. ${ }^{1}$

Di samping bahaya bagi individu pelakunya, homoseks juga membahayakan masyarakat. Jika individu enggan menikah, dan melampiaskan nafsu seksnya secara tidak legal, dengan sendirinya merusak sistem kekeluargaan dan merapuhkan landasan kemasyarakatan. Selanjutnya menimbulkan kehancuran akhlak, dan merenggangkan ikatan nilai-nilai dan norma agama yang akhirnya membawa kebebasan tanpa batas, seperti yang kita saksikan dalam masyarakat dewasa ini. ${ }^{2}$

\section{LGBT DALAM PERSPEKTIF FIQH JINAYAH}

Sebelum membahas LGBT dalam perspektif fiqh jinayah, perlu penulis jabarkan lebih dahulu sistematika hukum Islam. Hukum Islam bila disistematikan seperti tata hukum Indonesia, maka hukum Islam dapat disistematikan manjadi dua yaitu Hukum Perdata Islam dan Hukum Publik Islam. Hukum perdata Islam meliputi:

a. Munakahat, yang mengatur segala sesuatu yang berhubungan dengan perkawinan, perceraian serta akibat-akibat hukumnya;

b. Wirãsah, mengatur segala masalah yang berhubungan dengan pewaris, ahli waris, harta peninggalan serta pembagian warisan; dan

c. Muamalah, dalam arti yang khusus mengatur masalah kebendaan dan hak-hak atas benda, tata hubungan manusia dalam soal jual beli, sewa menyewa, pinjam meminjam, perserikatan dan sebagainya. ${ }^{3}$

Sedangkan hukum publik Islam meliputi:

d. Al-abkiam al-Sulthaniyah, yang membicarakan hubungan dengan kepala negara, pemerintahan, baik pemerintah pusat maupun daerah, tentara, pajak dan sebagainya.

e. Siyãr, mengatur urusan perang dan damai, tata hubungan dengan pemeluk agama dan negara lain.

f. Mukhasamat, mengatur soal peradilan, kehakiman, dan hukum acara.

g. Jinãyah / Jarimah, ${ }^{4}$ yang memuat aturan-aturan mengenai perbuatan-perbuatan yang diancam dengan hukuman, baik dalam jarimah hudud, qishash, dan ta'zir.

Sistematika hukum Islam di atas apabila dianalogikan dengan sistematika hukum Indonesia, maka munakahat dapat disamakan dengan hukum perkawinan; wirãsah sama dengan hukum kewarisan; muamalah sama dengan hukum benda dan hukum perjanjian; jinayah sama dengan hukum pidana; al-

\footnotetext{
${ }^{1}$ Ibid.

2 Ibid., hlm. 200.

${ }^{3}$ Lihat Mohammad Daud Ali, Hukum Islam; Pengantar Ilmu Hukum dan Tata Hukum Islam di Indonesia (Jakarta: Rajawali Press, 1990), hlm. 51. Bandingkan dengan Rahmat Rosyadi dan Rais Ahmad, Formalisasi Syariat Islam dalam Perspektif Tata Hukum Indonesia (Bogor: Ghalia Indonesia, 2006), hlm. 52-53.

4 Para fuqaha sering menggunakan istilah jinayah atau jarimah sama, karena istilah tersebut mempunyai kandungan arti yang sama. Mahrus Munajat, Rekonstruksi Hukum Pidana Islam, cet. ke-I (Yogyakarta: Logung Pustaka,
} 2006), hlm. 3. 
abkam al-Suthaniyah sama dengan hukum ketatanegaraan, yaitu hukum Tata Negara (HTN) dan Administrasi Negara (HTN); siyär sama dengan hukum Internasional; dan mukhasamat, sama dengan hukum acara.

Jarimah hudud adalah perbuatan pidana yang telah ditentukan bentuk dan batas hukumannya dalam al-Qur'an dan sunnah Nabi Muhammad (budud jamak dari had = batas). Jarimah qishash yaitu perbuatan yang diancam dengan hukuman qishash dan diyat. Hukuman qishash maupun diyat merupakan hukuman yang telah ditentukan batasannya, tidak ada batas terendah dan tertinggi, tetapi menjadi hak perorangan (si korban atau walinya). Sedangkan jarimah ta'şir adalah perbuatan pidana yang bentuk dan ancaman hukumannya ditentukan oleh penguasa (uli al-amr) sebagai pelajaran bagi pelakunya. ${ }^{1}$

\section{Tujuan Pembidanaan dalam Islam}

Dalam menetapkan hukuman pada suatu tindak pidana, tentunya tidak akan terlepas dari tujuan pemidanaan. Dengan melihat tujuan pemidanaan ini diharapkan pemberian hukuman dapat berjalan sesuai fungsingnya. Hukuman bukan suatu tujuan akhir, hukuman hanya sebagai suatu alat untuk mencapai tujuan tersebut.

Secara umum, tujuan pemidanaan dalam hukum Islam mengacu kepada tujuan-tujuan yang luas dari syariah, yaitu terciptanya keadilan dan kemaslahatan. Kemaslahatan itu dapat diwujudkan apabila lima unsur pokok dapat diwujudkan dan dipelihara. Menurut al-Syatibi, kelima unsur pokok itu adalah agama (bifdz, al-di), keturunan (bifdz, an-Nasl), akal (bifdz, al-aql), jiwa (bifdz an-Nafs) dan harta (bifdz almall). Dalam usaha mewujudkan dan memelihara lima unsur pokok tersebut, ia membagi kepada tingkat maqasid asy-Syariah atau tujuan syariah, yaitu kepentingan asas primer (maqasid ad-daruriyat), kepentingan atas dasar kebutuhan biasa/sekunder (maqasid al-hajiyat), dan kepentingan atas dasar kebutuhan tertier (maqasid at-tabsiniyat). Maqasid al-daruriyat dimaksudkan untuk menjaga dan memelihara lima unsur pokok dalam kehidupan manusia tersebut. Sedang maqäsid al-hajzyat bertujuan untuk menghilangkan kesulitan atau menjadikan pemeliharaan terhadap unsur lima pokok menjadi lebih baik lagi. Maqāsid altahsiniyat dimaksudkan agar manusia dapat melakukan yang terbaik untuk penyempurnaan pemeliharaan lima unsur pokok. ${ }^{2}$

Menurut Abu Zahrah, tujuan pemidanaan ada dua, yaitu: adanya perlindungan moral kebaikan dan menjaga stabilitas umum dari hal-hal yang tidak terpuji serta adanya kemaslahatan. Meskipun moral kebaikan dan kemaslahatan merupakan dua prinsip yang berbeda, namun pada prinsipnya dua hal ini saling berhubungan, dimana satu prinsip yang satu tidak akan tercapai tanpa adanya prinsip yang lainnya. ${ }^{3}$

'Abd al-Qādir Awdah mengatakan bahwa terdapat dua prinsip dasar dalam tujuan pemidanaan Islam, yaitu menuntaskan segala perbuatan pidana dengan mengabaikan pribadi terpidana dan memperbaiki sikap terpidana sekaligus memberantas segala bentuk tindak pidana Memberantas segala bentuk tindak pidana yang bertujuan untuk memelihara stabilitas masyarakat, sedangkan untuk

\footnotetext{
${ }^{1}$ Ibid,. hlm. 12.

2 Asafri Jaya Bakri, Konsep Maqashid Syari'ah Menurut al-Syatibi, (Jakarta: PT Raja Grafindo Persada, 1996), hlm. $71-72$.

${ }^{3}$ Muhammad Abu Zahrah, al-Jarmah wa al-Uqübah fi al-Fiqh al-Islämi: Al'Uqüba, (ttp.: Dar al-Fiqr al- 'Arabiy, 1974), hlm. 31.
} 
pribadi terpidana bertujuan untuk memperbaiki sikap dan perilakunya. Dengan adanya hal ini, menurutnya hukuman bagi segala bentuk tindak pidana yang terjadi harus sesuai dengan kemaslahatan dan ketentraman masyarakat yang menghendaki.

\section{Penyimpangan Seksual (LGBT) Perspektif Jinayah}

Pasangan homoseks (gay dan Lesbian) termasuk dalam tindak pidana berat (dosa besar), karena termasuk perbuatan keji yang merusak kepribadian, moral dan agama. Oleh karenanya, syara' menentukan bahwa praktik homoseks merupakan jarimah (tindak pidana) yang dikatakan lebih keji daripada zina. ${ }^{2}$

Ulama fiqih sepakat mengharamkan homoseks dan sejenisnya. Keharaman tersebut sebin berdasarkan al.-Qur'an sebagaimana disebut di atas, juga berdasarkan:

a. kaidah fiqhiyah yang mengatakan :

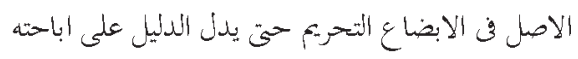

Pada dasarnya hubungan seks adalah haram, sehingga ada dalil (sebab-sebab yang jelas dan yakin tanpa keraguan) yang menghalalkannya, yakni adany a kad nikah.

b. Hadits Nabi

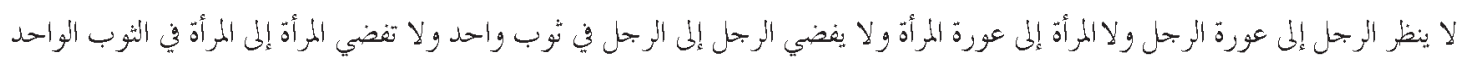

Seorang laki-laki tidak boleh melihat aurat laki-laki lain, dan seorang perempuan tidak boleh melihat aurat perempuan lain. Seorang laki-laki tidak boleh bersatu (bercampur) dengan laki-laki lain dalam satu pakaian, dan seorang perempuan tidak boleh bercampur dengan perempuan lain dalam satu pakaian. (HR. Muslim, Ahmad, Abu Dawnd \& Tirmidri).

Dari uraian di atas dapat disimpulkan, bahwa perbuatan gay dan lesbian adalah haram hukumnya. Adapun terkait dengan perilaku biseksual, prilaku ini diangap menjadi perilaku yang abnormal dikarenakan pola seksual yang dilakukan oleh manusia tersebut tidak wajar. Prilaku biseksual selain dapat menyukai sesame jenis, mereka juga dapat menyalurkan seksnya pada obyek lain seperti seperti melakukan hubungan seks dengan melalui dubur, onani/masturbasi menggunakan alat, menyetubuhi mayat atau hubungan seks dengan binatang. Perbuatan ini juga dilarang oleh agama dengan dasar ayat al-Qur'an:

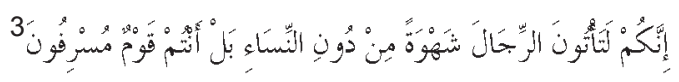

Sesungguhnya kamu mendatangi lelaki untuk melepaskan nafsumu (kepada mereka), bukan kepada wanita, malah kamu ini adalah kaum yang melampani batas.

Selain ayat di atas, dalil pelarangan biseksual juga adalah berdasarkan hadits nabi yang diriwayatkan oleh Ibnu Abbas :

$$
\text { لا ينظر المي رجل أثى رجهلا أو أمرأمة في دبره }
$$

1 'Abd al-Qādir Awdah, at-Tasyrî' al-Jināî̀ al- Islāmi, (Beirut: Massatu al-Risalatu, 1992), hlm. 633.

2 Dikatakan lebih keji dari perbuatan zina karena perbuatan ini bertentangan dengan akhlak dan fitrah manusia dan sebenarnya berbahaya bagi kehidupan manusia yang melakukannya. Lihat Sayyid Sabiq, Fiqh al-Sunnah., hlm. 361 .

3 Al-A'raf, (7) : 81. 
Allah tidak akan melihat kepada seseorang yang mendatangi laki-laki atau perempuan di duburnya. (HR. Tirmidri dan An Nasa’i dengan sanad shobib.)

Sedangkan dalam masalah Transgender hukumnya dapat dibagai dua, hal ini sebagaimana fatwa MUI dalam Musyawarah Nasional II Tahun 1980 tentang Operasi Perubahan atau Penyempurnaan Kelamin yang menyatakan bahwa mengubah jenis kelamin laki-laki menjadi perempuan atau sebaliknya adalah haram hukumnya, hal ini karena bertentangan dengan al-Qur'an dan bertentangan pula dengan jiwa Syara'. ${ }^{1}$ Fatwa MUI ini sejalan dengan dalil hadits nabi dari Ibnu Abbas:

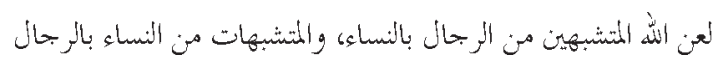

Allah melaknat laki-laki yang menyerupai wanita, begitu pula wanita yang menyerupai lakilaki. (HR. Bukhari).

Begitu pula dalam hadits Nabi dari Abu Hurairah,

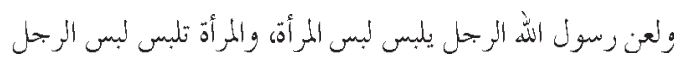

Rasulullah melaknat laki-laki yang memakai pakaian wanita, begitu pula wanita yang memakai pakaian laki laki" (HR. Abmad)

\section{Sanksi Pidana Pelaku LGBT Dalam Islam}

Para ulama telah sepakat gay (al-Liwath) dan lesbian (as-Sibaq) yang dinamai homoseksual merupakan perbuatan tindak pidana (jarimah zina), dan hukuman terhadap pelakunya adalah hukuman yang berat, hanya saja di antara para ulama tersebut ada perbedaan pendapat dalam menentukan ukuran/menetapkan hukuman apakah dalam bentuk had atau ta'rir. Kesepakatan status hukum gay dan lesbi (homoseks) di atas didasarkan pada dalil atQuran:

$$
3 \text {....... }
$$

Dan terhadap dua orang yang melakukan perbuatan keji di antara kamu, maka berilah hukuman kepada keduanya.

Serta hadits nabi yang diriwayatkan oleh Al-Baihaqi dari Abu Musa Al-'Asy'ari:

$$
\text { إذا أتى الر جل الر جلى فهما زانيان، وإذا أتت المرأة ألمرأة فهما زانيتان }
$$

"Tika seorang laki-laki menyetububi seorang laki-laki lainnya maka keduanya adalab orang yang berinina. Dan jïka wanita bersetubuh dengan wanita maka keduanya berzina, (HR. Baibaqi)

Mengenai hukuman ('uqubah)nya, menurut mazhab Malikiyah, Hanabilah, dan Syafi'iyah hukumannya adalah hukuman rajam dengan dilempari batu sampai mati, baik pelakunya maupun yang dikerjainya, baik itu jejaka maupun sudah berkeluarga (nikah). Alasannya dari tiga mazhab ini adalah homoseksual ini bentuknya sama dengan zina dalam segi memasukkan alat kelamin dengan syahwat dan kenikmatan. Dengan demikian, tindak pidana ini termasuk kepada kelompok zina

1 “Fatwa MUI Tahun 1980 tentang Operasi Perubahan atau Penyempurnaan Kelamin, http://mui.or.id. Akses 16 September 2016.

2 Seperti pendapat Imam Malik, Syafi'i, Ahmad, Abu Hanifah, Muhammad bin Hasan dan Abu Yusuf, mereka menghukumi homoseks sebagai zina, alasannya karena homoseks (gay dan Lesbi) keduanya disebut dengan fahisyah.

Lihat Ahmad Wardi Muslich, Hukum Pidana Islam, cet. ke-1 (Jakarta: Sinar Grafika, 2005), hlm. 12.

3 An-Nisa', (4) : 10. 
dengan hukuman-hukuman yang sudah tercantum dalam nas. ${ }^{1}$ Selain itu alasan mereka bahwa pelaku homoseks harus dibunuh (rajam) adalah berdasarkan hadits:

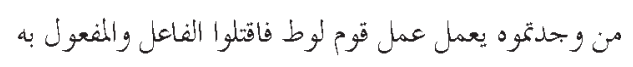

Barang siapa yang kamu dapati melakukan perbuatan kaum Nabi Luth (bomoseksual) maka bunublah si pelaku dan yang dikerjainya. (HR. lima abli badis kecuali Nasa'i)

Dari alasan di atas, jelas bahwa uqubah dari jarimah liwath dan As-sahaq, para ulama mazhab sepakat ${ }^{2}$ bahwa pelaksanaan sanksinya adalah sama dengan hukuman had zina, yaitu apabila ia ghair mubshan maka didera (cambuk) seratus kali ditambah dengan pengasingan selama satu tahun, dan apabila ia mubshan maka ia dirajam (lempar dengan batu) sampai mati.

Terhadap kasus biseksual dan transgender tidak dianggap sebagai zina yang dikenai hukuman had melainkan hanya tergolong pada perbuatan maksiat yang diancam dengan hukuman ta' 2 ir walaupun perbuatannya itu merupakan pendahuluan dari zina. Contoh seperti mufakhadzah (memasukkan penis di antara dua paha), atau memasukkan ke dalam mulut atau sentuhan-sentuhan di farji, berciuman, berpelukan atau perbuatan maksiat yang lain yang juga merupakan pendahuluan dari zina dikenai hukuman $t a^{\prime}$ zir $^{3}$ (yaitu sanksi hukuman kewenangannya diberikan pada pemerintah, hukuman tersebut dapat dalam bentuk penjara, denda atau lainnya).

Demikian halnya dengan transgender (khuntsa), dimana pelakunya menyerupai (tasyabbub) lain jenis, baik dalam berbicara, berbusana, maupun dalam berbuat, termasuk dalam aktivitas seksualnya, maka hukumannya dibagi dua, pertama jika transgender itu hanya menyerupai dalam bentuk lain jenis, baik dalam berbicara, berbusana, maupun dalam berbuat, maka sanksi dari jarimah ini adalah berbentuk ta'zir berupa pengusiran dari tempat tinggalnya. Hal ini berdasarkan hadits nabi yang diriwayatkan Ibnu Abbas:

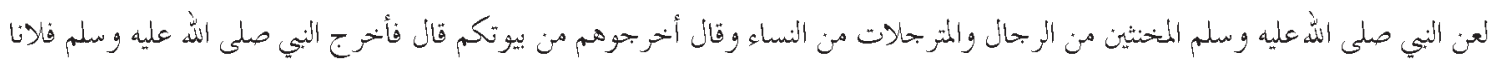

$$
\begin{aligned}
& \text { أنخرج عمر فلانا }
\end{aligned}
$$

Nabi telah mengutuk orang-orang waria (mukhannats) dari kalangan laki-laki dan orang-orang tomboy (mutarajilat) dari kalangan perempuan. Dan Nabi berkata, "Usillah mereka dari rumakrrumah kalian." (akbrijühum min buyütikum). Maka Nabi pernah mengusir fultan dan Umar juga pernah mengusir futan (HR Bukhari)

Dari hadits di atas jelas bahwa siapapun laki-laki berkelakuan seperti wanita atau sebaliknya, maka harus diasingkan jauh dari kerabat dan sanak saudara juga dari teman-teman yang telah mempengaruhinya. Adapun hukum kedua ialah jika transgender tersebut melakukan hubungan seksual maka hukumannya disamakan dengan jarimah budud zina.

1 Abd Ar-Rahman Al-Jaziri, Kitab Al-Fiqh 'ala Al-Madz̨abib Al-Arba 'ah, Juz V, (Beirut: Dār Al-Fikr, Beirut, 1980), hlm. 140 dalam Wardi Muslich, Hukum Pidana., hlm. 13.

${ }^{2}$ Kecuali Imam Abu Hanifah yang berpenadapat bahwa hukuman bagi homoseksual adalah ta' zir, karena wathi pada dubur (homoseksual) tidak dianggap sebagai zina, baik yang di wathi itu laki-laki maupun perempuan. Alasannya adalah wathi pada qubul disebut zina sedangkan wathi pada dubur disebut liwath. Dengan demikian, perbedaan nama tentunya menunjukkan perbedaan arti. Andaikata liwath dianggap sebagai zina, tentunya para sahabat Nabi tidak akan berselisih pendapat mengenai masalah ini. Di samping itu, zina menimbulkan kekacauan dalam keturunan dan menyebabkan tersia-sianya anak yang lahir tanpa ayah, sedangkan liwath (homoseksual) tidak menyebabkan demikian. Lihat 'Abd al-Qādir Awdah, at-Tasyrì' al-Jināî., hlm. 353. Lihat juga Wardi Muslich, Hukum Pidana., hlm. 14.

${ }^{3}$ Ibid. hlm. 8-9. 


\section{KESIMPULAN}

Islam sangat melarang dan melaknat Lesbian, Gay, Biseksual dan Transgender (LGBT), karena hal ini dipandang tidak sesuai dengan kodrat penciptaan manusia yang diciptakan untuk hidup berpasang-pasangan melalui pernikahan. Oleh karenanya, prilaku menyimpang LGBT termasuk perbuatan jarimah (tindak pidana/kriminal) dalam Islam. Dan untuk sanksi pidananya dapat diklasifikasikan tiga, yaitu pertama pelaku homoseksual (al-Liwath/as-Sihaq) dapat dikategorikan jarimah zina dan hukuman ("uqubah)nya adalah sama dengan hukuman had zina, yaitu apabila ia ghair mubshan maka didera (cambuk) seratus kali ditambah dengan pengasingan selama satu tahun, dan apabila ia mubshan maka ia dirajam (dilempar dengan batu) sampai mati. Kedua, terhadap pelaku biseksual tidak dapat dikategorikan sebagai jarimah zina yang dikenai hukuman had melainkan hanya tergolong pada perbuatan maksiat yang diancam dengan hukuman ta' 2 ir, yaitu hukumannya diberikan kewenangannya pada pemerintah, hukuman tersebut dapat dalam bentuk penjara, denda atau lainnya. Ketiga terhadap transgender (khuntsa mukhannats atau mularajilat), bila pelakunya hanya menyerupai (tasyabbuh) lain jenis, baik dalam berbicara, berbusana, maupun dalam berbuat, maka sanksi pidananya adalah berbentuk ta'zir dengan cara diusir dari tempat tinggalnya. Akan tetapi bila transgender (khuntsa mukhannats atau mutarajiliat) tersebut melakukan hubungan seksual maka hukumannya disamakan dengan jarimah budud zina.

\section{REFRENSI}

Al-Awaysyah, Husain. 1983. Al-Mausu'ah Al-Fiqhiyah Al-Muyassarah, juz 36, ttp.: Kementrian Wakaf dan Urusan Agama Kuwait.

Ali, Mohammad Daud. 1990. Hukum Islam; Pengantar Ilmu Hukum dan Tata Hukum Islam di Indonesia, Jakarta: Rajawali Press.

Al-Jaziri, Abd Ar-Rahman. 1980. Kitab Al-Figh 'ala Al-Madzabib Al-Arba 'ah, Juz V, Beirut: Dār AlFikr, Beirut.

Alusy, Rubul Ma’an’', Volume VIII, ttp. Tnp: tt.

Awdah, 'Abd al-Qādir. 1992. at-Tasyru’ al-Jināîa al- Islāmi, Beirut: Massatu al-Risalatu.

“Berapa Sebenarnya Jumlah Gay di Seluruh Indonesia?” http://nasional.republika.co.id. Akses 10 September 2016.

Bakri, Asafri Jaya. 1996. Konsep Maqashid Syari'ab Menurut al-Syatibi, Jakarta: PT Raja Grafindo Persada.

Departemen Agama RI. 1998. Al-Qur'an dan Terjemahnya, Semarang: PT Karya Thoha Putra.

"Fatwa MUI Tahun 1980 tentang Operasi Perubahan atau Penyempurnaan Kelamin, http://mui.or.id. Akses 16 September 2016.

https://id.wikipedia.org/wiki/Biseksualitas. Akses 10 September 2016.

https://id.wikipedia.org/wiki/Lesbian

Majma' at-Lughah al-'Arābiyah, al-Mu'jam al-W asith, cet. II, Jilid II, Mishr: Dar al- Ma'ārif, 1393 H1973 M.

Munajat, Mahrus. 2006. Rekonstruksi Hukum Pidana Islam, cet. ke-I, Yogyakarta: Logung Pustaka.

Munawwir, Ahmad Warson. 1997. Kamus Al-Munawir, cet. XIV, Surabaya; Pustaka Progressif.

98 RAHEEMA: J urnal Studi Gender dan Anak 
Muslich, Ahmad Wardi. 2005. Hukum Pidana Islam, cet. ke-1, Jakarta: Sinar Grafika.

Mutahhari, Murtadha. 1984. Manusia dan Agama, Bandung: Mizan.

Nadia, Zunly. 2005. Waria, Laknat atan Kodrat, Yogyakarta: Marwa.

"Perjalanan Organisasi LGBT di Indonesia", https://www.chanelmuslim.com. akses 15 September 2016.

Rangkuti, Ramlan Yusuf. 2012. "Homoseksual Dalam Perspektif Hukum Islam” dalam Jurnal AsySyir'abl Ilmu Syariah dan Hukum Vol. 46 No. I, Januari-Juni.

Ridha, Rasyid. 1950. Tafsir al-Manar, Kairo: Mathba’ah Hajari.

Rizqiyanto, Saumi. "Alasan Amerika Melegalkan Pernikahan Sesama Jenis", http://www.kompasiana.com/saumiere/alasan-amerika-melegalkan-pernikahan-sesama-jenis, Akses 16 September 2016.

Rosyadi, Rahmat dan Rais Ahmad. 2006. Formalisasi Syariat Islam dalam Perspektif Tata Hukum Indonesia, Bogor: Ghalia Indonesia.

"Sejarah Asal Usul Gay dan Waria Sampai Sekarang" http://danish56.blogspot.co.id, akses 16 September 2016.

Sa’abah, Marzuki Umar. 1998. Seks dan Kita, cet. ke-1, Jakarta: Gema Insani Press.

Sabiq, Sayyid. 1980. Figh al-Sunnah, juz VI, Beirut: Dar al-Fikr.

Yakan, Fathi. 1989. al-Islām wa al-Jins, Terj. Syafril Halim, Islam dan Seks, Jakarta: Al-Hidayah.

Zahrah, Muhammad Abu. 1974. al-jarimah wa al-Uqübah fí al-Fiqh al-Islami: Al'Uqüba, ttp.: Dar al-Fiqr al- 'Arabiy. 